DOI: https://doi.org/10.11144/Javeriana.upsy16-4.rdfd

\title{
The Role of Dispositional Flow's Dimensions in the Prediction of Intention to be Physically Active in Adolescents
}

\section{El rol de las dimensiones del flow disposicional en la predicción de la intención de ser físicamente activo en adolescentes}

\author{
Evelia Franco \\ Universidad de Alcalá, España \\ ORCID: http://orcid.org/0000-0002-6713-2767 \\ JAVIER Coterón \\ Universidad Politécnica de Madrid, España \\ Valeria Gómez \\ Universidad de Flores, Argentina \\ JaVier Pérez-Tejero \\ Universidad Politécnica de Madrid, España
}

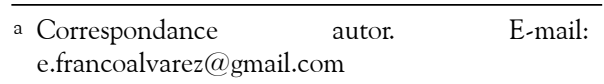

How to cite: Franco, E., Coterón, J., Gómez, V., \& Pérez-Tejeiro, J. (2017). The Role of Dispositional Flow's Dimensions in the Prediction of Intention to be Physically Active in Adolescents. Universitas Psychologica, 16(4), 1-11. https://doi.org/10.11144/Jav eriana.upsy16-4.rdfd

\begin{abstract}
Within the flow theory framework, the aims of this study were a) to analyze differences in flow dimensions and future physical activity (FPA) practice intentions according to the level of current PA and b) to analyze the predictive role of flow dimensions for FPA practice intentions. The sample was composed by 1076 physical education students and segmented according to the current PA levels. Subjects reporting high levels of PA scored higher in all of the flow dimensions. Stepwise regression analyses indicated that autotelic experience was associated with FPA practice intentions among all of the participants. Furthermore, in the lowactivity group the balance between challenge and skills also emerged as a predictor, while in the high-activity group both the sense of control and the perception of clear objectives resulted significant in the explanation of FPA practice intentions. The findings suggest that the implementation of different strategies to enhance dispositional flow in physical education settings may have the potential to increase FPA intentions, especially those oriented to enhance autotelic experience.

Keywords

Motivation; adolescents; dispositional flow; metabolic equivalence of task.
\end{abstract}

\section{RESUMEN}

Enmarcado en la teoría del flow, este estudio pretende a) comprobar las diferencias en las dimensiones del flow disposicional y en la intención futura de realizar actividad física (IF) según el nivel de AF y b) estudiar el papel predictivo de dichas dimensiones sobre la IF. La muestra estuvo compuesta por 1076 estudiantes de educación física y se segmentó según el nivel actual de AF. Los sujetos que mostraron mayores niveles de AF presentaron valores más elevados en todas las dimensiones. Los análisis de regresión por pasos indicaron que la experiencia autotélica se asoció con IF en todos los participantes. Además, en el grupo de baja actividad el equilibrio percibido entre el reto y la habilidad emergió como predictor mientras que en el grupo de alta actividad, tanto la sensación 
de control como la percepción de objetivos claros resultaron significativos en la explicación de la IF. Los resultados sugieren que la implementación en clases de EF de diferentes estrategias para mejorar la disposición a experimentar el flow, puede aumentar la IF.

Palabras clave

motivación; adolescentes; flow disposicional; índice metabólico.

Several studies have shown the physical and psychological benefits of physical activity for children and young people (Biddle, Sallis, \& Cavill, 1998). However, the amount of time actually spent being physically active rarely reaches the general recommendations proposed for these groups (Currie et al., 2008). In addition, an important drop in the physical activity levels during adolescence has been observed in recent years (Wall \& Côté, 2007).

Physical education (PE) is a mandatory activity for students at ages in which subjects show high levels of susceptibility to abandoning physical activity. Therefore, PE class is an attractive context for analyses and interventions related to the promotion of physical activity, which has been shown in many studies conducted over the last few years (Gil-Madrona \& MartínezLópez, 2015; Méndez-Giménez, Fernández-Río, \& Cecchini, 2015; Moreno-Murcia, Huéscar, Peco, Alarcón, \& Cervelló, 2012; Sánchez-Oliva, Leo, Amado, Pulido, \& García-Calvo, 2015). Children's intentions to practice a sport or any other physical activity can be a good indicator of their motivation towards that activity as well as a strong predictor of future behaviors (e.g., Shephard \& Trudeau, 2000).

\section{Flow experience}

A flow state refers to an optimal experience that people report when they are completely involved in something to the point of forgetting time, fatigue, and everything else but the activity itself (Csikszentmihalyi, Abuhamdeh, \& Nakamura, 2005). Experiencing this positive state while doing physical activity can lead to better performance (Jackson, Thomas, Marsh, \& Smethurst, 2001) and higher levels of participation in physical activity (Jackson, 1996; Jiménez-Torres, Godoy-Izquierdo, \& Godoy García, 2012; Kimiecik, 2000). People who achieve the flow state when taking part in a physical activity are able to reach high levels of fun and enjoyment, and these feelings encourage them to repeat the activity to keep experiencing these emotions (Kimiecik, 2000).

Csikszentmihalyi (1990) proposes that the flow state is composed of nine main components: balance between challenge and skills, merging of action and awareness, clear goals, unambiguous feedback, concentration on the task, sense of control, loss of self-consciousness, distortion of the sense of time, and autotelic experience.

Two different aspects of the flow concept can be distinguished: the flow state and the dispositional flow. The first is defined as the immediate level of the flow experience (as it has been described earlier), and the second refers to the propensity to experience flow (Jackson et al., 2001).

\section{Flow as a study variable}

The majority of research undertaken on physical activity has considered flow as a onedimensional variable (Amado, Sánchez-Miguel, Leo, Sánchez-Oliva, \& García-Calvo, 2013; Coterón, Sampedro, Franco, Pérez-Tejero, \& Refoyo, 2013), although there are works that have considered the composition of flow in the different dimensions (Jackson et al., 2001; Sicilia, Águila, González-Cutre, \& Moreno, 2010; Sicilia, Moreno, \& Rojas, 2008).

Previous research suggests that of the nine dimensions initially developed by Csikszentmihalyi, some aspects are more important than others for the experience of flow in sports (Jackson, 1996; Jackson, Kimiecik, Ford, \& Marsh, 1998). Csikszentmihalyi (e.g., Csikszentmihalyi \& LeFevre, 1989) has mainly analyzed the balance between challenge and skills for measuring the flow state, whereas other authors (Jackson, 1996) consider autotelic experience to be essential for the flow state to appear. 
More recently, Csikszentmihalyi et al. (2005) have provided a phenomenological explanation for the origin of motivation in the subject through flow. They established the merging of action and awareness ("psychic entropy"), sense of control, and distortion of the sense of time as flow characteristics. At the same time, they noted the balance between the challenge and skills, clear goals, and unambiguous feedback as flow preconditions rather than characteristics by themselves.

Because contributions from several lines of research have suggested that the conceptualization of the flow state, including its conditions and characteristics, is a dynamic process which is still being developed, it appears that new studies are necessary to define the importance and predictive role of each dimension.

Flow in PE has been traditionally analyzed as a dependent variable and its study has been especially focused on the analysis of factors that influence the experience of flow. Some of the predictive elements that appear in the literature more frequently are well-being, perceived competence, autonomy, relatedness or task-involving state (e.g., Kowal \& Fortier, 2000; Mandigo \& Thompson, 1998; Sicilia et al., 2010; Sicilia et al., 2008).

Several studies in the field of physical activity emphasize the close relationship between the flow state and intrinsic motivation (e.g., Kowal \& Fortier, 2000; Mandigo \& Thompson, 1998). Intrinsic motivation, defined as the selfdetermined or intrinsic behavior that is reflected when the individual participates for the sake of the activity as an end in itself, is a key element in the Self-Determination Theory (Deci \& Ryan, 1985, 2000), one of the most important frameworks used for the study of motivation over the last few decades.

The existing literature abounds with studies whose results have established a relation between intrinsic motivation and future physical activity intentions or practice adherence (e.g., GraneroGallegos, Baena-Extremera, Sánchez-Fuentes, \& Martínez-Molina, 2014; Moreno-Murcia et al., 2012; Zhang, Solmon, Kosma, Carson, \& Gu,
2011). However, there are few studies that have established a direct relation between the flow state and future physical activity practice intentions (Tipler, Marsh, Martin, Richards, \& Williams, 2004).

\section{Aims of our study}

The objectives of the present study are a) to test whether there are any differences in the flow components and future physical activity practice intentions according to the level of current physical activity; and b) to analyze the predictive role of each of these components on the future physical activity practice intentions.

\section{Methods}

\section{Participants}

An initial sample of 1076 students (520 boys and 556 girls), ages 12 to 18 years old $(\mathrm{M}=$ 15.24 years, $D T=1.63)$, from physical education classes in different public and private schools in Madrid (Spain) was used. The students belonged to 4 courses of mandatory secondary schooling and one post-mandatory year in the Spanish educational system. The participants were selected through a simple random sampling among the centers that voluntarily agreed to take part in the study. Following the procedure described in the Statistical Analysis section, a part of this sample was selected for the study $(\mathrm{n}=542)$. Subjects were grouped in two sets depending on their level of physical activity practice. Thus, the low physical activity participation group was formed by 276 subjects (94 boys and 182 girls), ages 12 to 18 years old $(M=15.16$ years, $D T=1.59)$. On the other hand, the high physical activity participation group was formed by 266 subjects (162 boys and 104 girls), ages 12 to 18 years old $(M=14.12$ years, $D T=1.58)$. 


\section{Measures}

\section{Dispositional flow}

The Spanish version (García Calvo, Jiménez, Santos-Rosa, Reina, \& Cervelló, 2008) of the Dispositional Flow Scale-2 ([DFS-2]; Jackson \& Eklund, 2002) was used to measure students' disposition toward experiencing a flow state in their PE classes. This scale had 36 items (e.g., "I am challenged, but I believe my skills will allow me to meet the challenge," "Things just seem to happen automatically," "My attention is focused entirely on what I am doing," "I have a sense of control over what I am doing," "I really enjoy the experience"), which were answered using a 5-point Likert-type scale, from 1 (never) to 5 (always). The DFS-2 consisted of nine factors (four items for each factor) that made reference to the components leading to the flow state. This study obtained a Cronbach's alpha of 0.77 for challenge-skills balance, 0.77 for actionawareness merging, 0.78 for clear goals, 0.74 for unambiguous feedback, .77 for concentration on the task at hand, 0.79 for sense of control, .84 for loss of self-consciousness, 0.79 for transformation of time, and .83 for autotelic experience.

\section{Level of current physical activity}

A modification of Godin and Shephard's (1985) Leisure Time Exercise Questionnaire (G-LTEQ) was used to assess leisure-time physical activity. An expert group adapted the examples of the activities in the questionnaire to be more suitable for Spanish habits. The questionnaire asked how many days per week participants engaged in vigorous, moderate, and mild exercise for at least 30 minutes. A composite exercise behavior score was then calculated using the weighted sum of each exercise intensity according to the following formula: $($ mild $\times 3)+($ moderate $\times 5)+$ (vigorous $x$ 9). The result was a weekly MET (metabolic equivalence of task).
Intention to be physically active

The adapted Spanish version (Moreno-Murcia, Moreno, \& Cervello, 2007) of the Intention to be Physically Active Questionnaire (Hein, Müür, \& Koka, 2004) was used. It is composed of five items for measuring the subject's intention to be physically active (for example, "I am interested in developing my physical fitness"). The items are preceded by the phrase "Regarding your intention to practice athletics...". The questions were responded to using a Likert scale that ranged from 1 (Strongly disagree) to 5 (Strongly agree). This study obtained a Cronbach's alpha of .82 .

\section{Procedure}

The head teachers of the different schools were informed about the project and their consent to conduct the study was requested. Once institutional permission was given, questionnaires were administered during the $\mathrm{PE}$ classes by a member of the research team who was previously trained. This person provided a brief explanation of the purpose of the study, informed the participants about the proper way to complete the measures, solved any complications, and made sure that the anonymity of the participants was maintained, as well as encouraged them to provide their most honest answers to the questions. The survey took approximately 20 minutes to complete, although this time varied according to the age of the participants.

\section{Statistical Analysis}

The sample was segmented according to the current physical activity levels reported by the participants. This approach, which is based on splitting the sample according to the scores obtained, has been used previously (Ommundsen \& Roberts, 1999), and it was selected instead of a cluster analysis because only one continuous variable (PA levels) was considered in forming 
the groups. To make the detection of differences easier, information from the extreme quartiles was used, and two groups were established: a low-activity group (subjects in the percentile $\leq$ 25; MET between 0 and 37) and a high-activity group (subjects in the percentile $\geq 75$; MET between 74 and 119). Descriptive analyses of all variables and a students' t-test were performed in order to analyze differences between lowand high- activity groups. Lastly, a stepwise regression analysis using the intention to be physically active as the dependent variable and the flow dimensions as independent variables were performed. Data processing was performed using SPSS 20.

\section{Results}

Descriptive statistics, correlations, and differences according to the current physical activity levels

Table 1 shows the descriptive statistics. Most of the participants reported relatively high scores in the nine flow components as well as in the intention to be physically active in the future. The differences found in all of the analyzed variables according to the current physical activity levels are noteworthy ( $p<0.001$ ). Students reporting the highest levels of physical activity showed the highest scores.
TABLE 1

Descriptive statistics and Students' t-test of the variables according to the current physical activity levels

\begin{tabular}{lccc}
\hline & $\begin{array}{c}\text { Low MET } \\
\text { M (SD) }\end{array}$ & $\begin{array}{c}\text { High MET } \\
\text { M (SD) }\end{array}$ & $p$ \\
\hline Balance between challenge and skills & $3.19(.86)$ & $3.80(.74)$ & 0.001 \\
Merging of action and awareness & $2.87(.85)$ & $3.53(.80)$ & 0.001 \\
Clear Goals & $3.43(.90)$ & $3.99(.76)$ & 0.001 \\
Unambiguous feedback & $3.23(.85)$ & $3.81(.77)$ & 0.001 \\
Concentration on the task & $3.22(.88)$ & $3.71(.82)$ & 0.001 \\
Sense of Control & $3.20(.86)$ & $3.84(.77)$ & 0.001 \\
Loss of self-consciousness & $3.32(1.07)$ & $3.67(1.04)$ & 0.001 \\
Distortion of the sense of time & $3.34(.93)$ & $3.90(.84)$ & 0.001 \\
Autotelic experience & $3.45(.93)$ & $4.03(.78)$ & 0.001 \\
Future intention to be physically active & $3.53(.96)$ & $4.36(.71)$ & 0.001 \\
\hline & Source: & & \\
\hline & &
\end{tabular}

Pearson bivariate correlations were performed to analyze the relations among the variables (Table 2). Notably, all of the flow dimensions correlated with the future intention to be physically active. Correlation indexes were higher among subjects who reported lower levels of current physical activity, except for the loss of self-consciousness dimension. In addition, the correlation was stronger for some dimensions, such as the balance between challenge and skills, clear objectives, sense of control, and autotelic experience. In these dimensions, the correlation index was above 0.5 among the low MET subjects and was approximately 0.4 among the high MET participants. 


\section{TABLE 2}

Bivariate correlations between flow dimensions and future intentions to be physically active

\begin{tabular}{|c|c|c|c|c|c|c|c|c|c|c|}
\hline Varial & & 1 & 2 & 3 & 4 & 5 & 6 & 7 & 8 & 9 \\
\hline IPA & $\begin{array}{l}\text { Low } \\
\text { MET }\end{array}$ & $0.549 * *$ & $0.410 * *$ & $0.547^{* *}$ & $0.488^{* *}$ & $0.410^{* *}$ & $0.504 * *$ & $0.208^{* *}$ & $0.446^{* *}$ & $0.564 * *$ \\
\hline IPA & $\begin{array}{l}\text { High } \\
\text { MET }\end{array}$ & $0.411^{* *}$ & $0.283^{* *}$ & $0.388^{* *}$ & $0.346^{* *}$ & $0.290^{* *}$ & $0.424 * *$ & $0.233^{*} *$ & $0.300^{* *}$ & $0.417 * *$ \\
\hline
\end{tabular}

Note.IPA $=$ Intention to be Physically Active, $1=$ Balance between challenge and skills, $2=$ Merging of action and awareness, $3=$ Clear goals,

$4=$ Unambiguous feedback, $5=$ Concentration on the task, $6=$ Sense of control, $7=$ Loss of self-consciousness, $8=$ Distortion of the sense of time and $9=$ Autotelic experience. $* *$ Significant correlation $(\mathrm{p}<0.001)$.

\section{Relationships between flow dimensions and future intention to be physically active}

To assess the relationships between the flow components and the future intention to be physically active, a stepwise regression analysis was performed (Tables 3 and 4).

Table 3 shows the stepwise regression analysis for the sample composed of the low MET subjects. Autotelic experience emerged as the most important predictor $(\mathrm{t}=11.17, \mathrm{p}<0.001)$, explaining $32 \%$ of the variance. In a second step, autotelic experience $(t=6, p<0.001)$ and balance between challenge and skills $(t=5.93, p$ $<0.001$ ) explained $40 \%$ of the variance.

\section{TABLE 3}

Coefficients of stepwise regression analysis in low MET subjects

\begin{tabular}{|c|c|c|c|c|}
\hline Variable & $\mathrm{B}$ & $\mathrm{R}^{2}$ adjusted & $t$ & $\mathrm{p}$ \\
\hline Step 1 & & \multirow{2}{*}{0.32} & & \\
\hline Autotelic experience & 0.59 & & 11.17 & 0.001 \\
\hline \multicolumn{5}{|l|}{ Step 2} \\
\hline Autotelic experience & 0.37 & \multirow{2}{*}{0.40} & 6 & 0.001 \\
\hline $\begin{array}{l}\text { Balance between } \\
\text { challenge and skills }\end{array}$ & 0.40 & & 5.93 & 0.001 \\
\hline
\end{tabular}

Table 4 shows the stepwise regression analysis for the sample formed by the high MET participants. Sense of control emerged as the best predictor $(\mathrm{t}=6.56, \mathrm{p}<0.001)$, explaining $15 \%$ of the variance. In a second step, sense of control $(\mathrm{t}=3.88, \mathrm{p}<0.001)$ and autotelic experience $(t=3.47, p<0.001)$ explained $19 \%$ of the variance. In the third step, apart from sense of control $(\mathrm{t}=2.01, \mathrm{p}<0.05)$ and autotelic experience $(t=3.03, p<0.01)$, clear objectives $(\mathrm{t}=2.36, \mathrm{p}<0.05)$ was included and $20 \%$ of the variance was explained.

\section{TABLE 4}

Coefficients of stepwise regression analysis in high

MET subjects

\begin{tabular}{lcccc}
\hline \multicolumn{1}{c}{ Variable } & $\mathrm{B}$ & $\mathrm{R}^{2}$ adjusted & $\mathrm{t}$ & $\mathrm{p}$ \\
\hline $\begin{array}{l}\text { Step 1 } \\
\begin{array}{l}\text { Sense of } \\
\text { control }\end{array}\end{array}$ & 0.34 & 0.15 & 6.56 & 0.001 \\
\hline $\begin{array}{l}\text { Step 2 } \\
\begin{array}{l}\text { Sense of } \\
\text { control }\end{array}\end{array}$ & 0.23 & 0.19 & 3.88 & 0.001 \\
$\begin{array}{l}\text { Autotelic } \\
\text { experience }\end{array}$ & 0.21 & & 3.47 & 0.001 \\
\hline $\begin{array}{l}\text { Step 3 } \\
\begin{array}{l}\text { Sense of } \\
\text { control }\end{array}\end{array}$ & 0.14 & 0.20 & 3.03 & 0.003 \\
$\begin{array}{l}\text { Autotelic } \\
\text { experience }\end{array}$ & 0.18 & & 0.051 \\
$\begin{array}{l}\text { Clear } \\
\text { objectives }\end{array}$ & 0.16 & 2.36 & 0.019 \\
\hline \multicolumn{3}{c}{ Source: own work } \\
\end{tabular}

\section{Discussion}

While flow has not been found to be a direct predictor of the intention to be physically active in the existing literature, it has been suggested that one's disposition toward experiencing this state can explain differences in participation in sports and physical activities (Jackson et al., 2001). Studies examining flow in different settings have shown evidence of a relationship between the experience of flow and satisfaction with the activity performed (Jackson, 1992), commitment (e.g., Csikszentmihalyi, 1990; Deci \& Ryan, 1985; Karageorghis, Vlachopoulos, $\&$ Terry, 2000), and experience of positive post-exercise feelings such as revitalization and tranquility (Karageorghis et al., 2000). Following this conclusion, experiencing flow during PE classes is of notable importance, as it can lead to the appearance of positive emotions during and after exercise which, in turn, could promote physical activity adherence (Sallis \& Hovell, 1990).

The first objective of our study was to test whether there were any differences in the flow 
components and future physical activity practice intentions according to the level of current physical activity.

We found that the high MET group reported higher scores in all of the flow components, as well as in the intention to be physically active in the future. There are few studies that have attempted to establish a relationship between the practice of physical activity and the disposition toward experiencing flow among adolescents. In a correlational study, MorenoMurcia, Alonso, Martínez-Galindo, and Cervelló (2005) found that students who reported doing some extracurricular physical activity showed higher levels of flow than those who did not engage in any activity during their leisure time. A similar study found a relationship between dispositional flow and extracurricular physical activity (Cervelló, Moreno, Alonso, \& Iglesias, 2006), suggesting that a higher propensity for experiencing flow might predict physical activity practices. Although previous studies have not considered the future intention to be physically active as a dependent variable, the existence of differences in the propensity for experiencing flow (as well as the variance in other variables such as satisfaction in PE class) according to the current physical activity level suggests that a relationship between current levels of physical activity and future intention to perform might exist (Malina, 2001).

The second objective of our study was to analyze the predictive role of each of the flow components for future physical activity practice intentions by considering the two previously established groups: low MET and high MET.

First, it must be noted that the correlation analyses showed a strong connection between all of the flow components and one's intention to be physically active for both groups. This suggests that, regardless of current physical activity level, the experience of flow might facilitate a more proactive attitude towards the continued physical activity practice.

A regression analysis showed an important presence of the dimension of autotelic experience as a predictive variable in both groups. This finding is in line with the theoretical foundation provided by Csikszentmihalyi (1990), who has occasionally used this term in reference to flow (Jackson, 1996). The relevance of this dimension has been subsequently tested and has been suggested to be a key element for the study of motivation in educational settings (Sicilia et al., 2010; Sicilia et al., 2008).

In the low MET group, the regression analysis showed that apart from autotelic experience, the balance between challenge and skills was a predictive factor of future intention to be physically active. This fact could be explained by the needs of the subjects in the low performance group to feel that they have sufficient resources to face the proposed challenges. This balance could make them feel driven to persist in the practice of physical activity. This balance between challenge and skills can be understood as a feeling of being competent enough to face a challenge. The study of competence, as one of the basic psychological needs established by self-determination theory, has been addressed through several studies over the last few years (e.g., Zhang et al., 2011). In line with the results in the present study, most of these works have established an association between feeling competent and be willing to take part in physical activities (Erdvik, Overby, \& Haugen, 2014; Weidong, Rukavina, \& Haichun, 2011). Findings of the present study suggest that satisfaction of competence might become especially relevant among adolescents who do not currently engage in physical activity.

In the high MET group, the regression analysis showed that a sense of control and clear objectives were predictive variables (as well as the autotelic experience). Individuals with a high level of practice lean on their mastery of the tasks to further progress and subsequently set new objectives to reach.

It is worth stressing that the association between flow dimensions and intention to be physically active in the future is stronger in subjects in the low MET group than in subjects of the high MET group. The correlation analysis showed that although association was significant in both groups, the strength of the correlation was higher in subjects belonging to the low MET group (Table 2). These results are in line with the 
regression analyses. As it is shown in Tables 3 and 4 , the variance of intention to be physically active explained by flow dimensions is higher among participants who report lower levels of physical activity. These findings suggest that, among those adolescents with lower levels of participation in physical activities, the phenomenological experience of flow would become a powerful motivating source. In line with Csikszentmihalyi et al. (2005), and other studies analyzing the role of dispositional flow in the prediction of physical activity intentions (Franco, Coterón, Gómez, Brito, \& Martínez-González, 2017), participation in physical activities would not continue unless they are enjoyable. Considering the findings of the present study it can be suggested that the importance of experiencing flow is especially relevant when it comes to people who are not highly engaged in physical activity. Further studies in this line would be needed to better understand the importance of the flow experience among adolescents who are not likely to take part in physical activity.

Taking into consideration the two different models that resulted from the regression analyses in this study, it could be worth adapting the suggestions provided by Mandigo and Thompson (1998) to the physical activity levels of the subjects. One such suggestion is to propose fun and enjoyable activities to pupils who report low physical practice levels because it is more likely that individuals engaging in contexts where enjoyment is promoted will continue to participate in some physical activity (Chen, 2013). Furthermore, in order to promote satisfaction of competence, it would be interesting to implement strategies aimed to increase autonomy as the evidence of a positive effect of interventions fostering the satisfaction of autonomy on the satisfaction of competence within physical activity contexts has been proven (Meng \& Keng, 2016; MorenoMurcia \& Sánchez-LaTorre, 2016). On the other hand, another suggestion is to allow subjects who usually engage in physical activity to modify or control some of the proposed activities according to their interests and skills because, for these students, the feeling of being in control encourages their intentions to practice physical activity in the future.

Lastly, the differences found in all the flow components support the consideration of flow as a one-dimensional variable that exists in the majority of previous research. However, some studies that have analyzed the different flow components have found significant differences among them (Charalambous \& Ntoumanis, 2000; Jackson et al., 2001; Sicilia et al., 2008). Similarly, the findings of this study have shown differences in the influence of the dimensions over the intention to be physically active in the future. It is suggested that further studies considering the predictive role of the flow components over different motivational variables are needed to clarify which of its dimensions can be observed as preconditions and characteristics, as well as to better understand flow.

\section{Acknowledgements}

This work is part of a larger project entitled "Improving our teenagers' health for a future life: motivation in physical education", supported by the Technical University of Madrid (Spain) [grant number AL14-PID-40].

\section{References}

Amado, D., Sánchez-Miguel, P. A., Leo, F. M., Sánchez-Oliva, D., \& GarcíaCalvo, T. (2013). Desarrollo de un modelo de motivación para explicar el flow disposicional y la ansiedad en bailarines profesionales. Universitas Psychologica, 12(2), 457-470.

Biddle, S., Sallis, J. F., \& Cavill, N. (1998). Young and active? Young people and health enhancing physical education: Evidence and implications. London: Health Education Authority.

Cervelló, E., Moreno, J. A., Alonso, N., \& Iglesias, D. (2006). Goal orientation, motivational climate, and dispositional flow of high school students engaged in exrtacurricular physical activity. Perceptual 
Eु Motor Skills, 102, 87-92. https:// doi.org/10.2466/PMS.102.1.87-92

Charalambous, M., \& Ntoumanis, N. (2000). Goal orientations and flow states in female volleyball players. Sport Psychology, 11, 55-76.

Chen, A. (2013). Top 10 research questions related to children physical activity motivation. Research Quarterly for Exercise Eु Sport, 84, 441-447. https:// doi.org/10.1080/02701367.2013.844030

Coterón, J., Sampedro, J., Franco, E., PérezTejero, J., \& Refoyo, I. (2013). The role of basic psychological needs in predicting dispositional flow of basketball players in training. Differences by sex. Revista de Psicología del Deporte, 22(1), 187-190.

Csikszentmihalyi, M. (1990). Flow. The psychology of optimal experience. New York: HarperCollins Publishers.

Csikszentmihalyi, M., Abuhamdeh, S., \& Nakamura, J. (2005). Flow. In A. J. Elliot \& C. Dweck (Eds.), Handbook of competence and motivation (pp. 598-608). New York: Guilford.

Csikszentmihalyi, M., \& LeFevre, J. (1989). Optimal experience in work and leisure. Journal of Personality and Social Psychology, 56(5), 815-822.

Currie, C., Gabhainn, S. N., Godeau, E., Roberts C., Smith, R., Currie, D., ... Barnekow, V. (Eds.). (2008). Inequalities in young people's health (Health Behaviour in School-Aged Children. International Report from the 2005/2006 Survey). Copenhagen, Denmark: WHO Regional Office for Europe. Retrieved from http://www.euro.who.int/ data/asset s/pdf_file/0005/53852/E91416.pdf

Deci, E. L., \& Ryan, R. M. (1985). Intrinsic motivation and self-determination in human behaviour. New York: Plenum.

Deci, E. L., \& Ryan, R. M. (2000). The "what" and "why" of goal pursuits: Human needs and the self-determination of behavior. Psychological Inquiry, 11(4), 227-268.

Erdvik, I. B., Overby, N. C., \& Haugen, T. (2014). Students' self-determined motivation in physical education and intention to be physically active after graduation: The role of perceived competence and identity. Journal of Physical Education and Sport, 14(2), 232-241. https://doi.org/10.7752/ jpes.2014.02035

Franco, E., Coterón, J., Gómez, V., Brito, J., \& Martínez-González, A. (2017). Influencia de la motivación y del flow disposicional sobre la intención de realizar actividad físico-deportiva en adolescentes de cuatro países. Retos, 31, 46-51.

García Calvo, T., Jiménez, R., Santos-Rosa, F. J., Reina, R., \& Cervelló, E. (2008). Psychometric properties of the Spanish version of the flow state scale. The Spanish Journal of Psychology, 11(2), 660-669.

Gil-Madrona, P., \& Martínez-López, M. (2015). Emociones auto-percibidas en las clases de educación física en primaria. Universitas Psychologica, 14(3), 923-936. https:// doi.org/10.11144/Javeriana.upsy14-3.eapc

Godin, G., \& Shephard, R. J. (1985). A simple method to assess exercise behavior in the community. Canadian Journal of Applied Sport Sciences, 10(3), 141-146.

Granero-Gallegos, A., Baena-Extremera, A., Sánchez-Fuentes, J. A., \& Martínez-Molina, M. (2014). Perfiles motivacionales de apoyo a la autonomía, autodeterminación, satisfacción, importancia de la educación física e intención de práctica física en tiempo libre. Cuadernos de Psicología del Deporte, 14(2), 59-70.

Hein, V., Müür, M., \& Koka, A. (2004). Intention to be physically active after school graduation and its relationship to three types of intrinsic motivation. European Physical Education Review, 10(1), 5-19. https:// doi.org/10.1177/1356336X04040618

Jackson, S. A. (1992). Athletes in flow: A qualitative investigation of flow states in elite figure skaters. Journal of Applied Sport Psychology, 4, 161-180. https:// doi.org/10.1080/10413209208406459 
Jackson, S. A. (1996). Toward a conceptual understanding of the flow experience in elite athletes. Research Quarterly for Exercise $\mathbb{E}$ Sport, 67(1), 76-90. https:// doi.org/10.1080/02701367.1996.10608859

Jackson, S. A., \& Eklund, R. C. (2002). Assessing flow in physical activity: The Flow State Scale-2 and Dispositional Flow Scale-2. Journal of Sport $\mathbb{E}$ Exercise Psychology, 4, 133-150. https:// doi.org/10.1123/jsep.24.2.133

Jackson, S. A., Kimiecik, J. C., Ford, S. K., \& Marsh, H. W. (1998). Psychological correlates of flow in sport. Journal of Sport Eु Exercise Psychology, 20, 358-378. https:// doi.org/10.1123/jsep.20.4.358

Jackson, S. A., Thomas, P. R., Marsh, H. W., \& Smethurst, C. J. (2001). Relationships between Flow, Self-Concept, Psychological Skills, and Performance. Journal of Applied Sport Psychology, 13(2), 129-153.

Jiménez-Torres, M. G., Godoy-Izquierdo, D., \& Godoy García, J. F. (2012). Relación entre los motivos para la práctica físico-deportiva y las experiencias de flujo en jóvenes: diferencias en función del sexo. Universitas Psychologica, 11(3), 909-920.

Karageorghis, C. I., Vlachopoulos, S., \& Terry, P. C. (2000). Latent variable modelling of the relationship between flow and exercise-induced feelings: An intuitive appraisal perspective. European Physical Education Review, 6(3), 230-248. https:// doi.org/10.1177/1356336X000063002

Kimiecik, J. C. (2000, January 1). Learn to love exercise. Psychology Today. Health Profs.com. Retrieved from https:/www.psychologytoday.com/ articles/200001/learn-love-exercise

Kowal, J., \& Fortier, M. S. (2000). Testing relationships from the hierarchical model of intrinsic and extrinsic motivation using flow as a motivational consequence. Research Quarterly for Exercise $\mathcal{E}$ Sport, 71, 171-181. https:// doi.org/10.1080/02701367.2000.10608895

Malina, R. M. (2001). Adherence to physical activity from childhood to adulthood: A perspective from tracking studies. Quest, 53(3), 346-355.

Mandigo, J. L., \& Thompson, L. (1998). Go with their flow: How flow theory can help practitioners to intrinsically motivate children to be physically active. Physical Educator, 55(3), 145-159.

Méndez-Giménez, A., Fernández-Río, J., \& Cecchini, J. A. (2015). Perfiles motivacionales de aproximaciónevitación en contextos de educación física. Universitas Psychologica, 14(2), 549-562. https://doi.org/10.11144/ Javeriana.upsy14-2.pmae

Meng, H. Y., \& Keng, J. W. (2016). The effectiveness of an autonomysupportive teaching structure in physical education. Ricyde, 12(43), 5-28. https:// doi.org/10.5232/ricyde

Moreno-Murcia, J. A., Alonso, N., Martinez, C., \& Cervelló, E. (2005). Motivación, disciplina, coeducación y estado del flow en educación física: diferencias según la satisfacción, la práctica deportiva y la frecuencia de práctica. Cuadernos de Psicología del Deporte, 5(1-2), 231-243.

Moreno-Murcia, J. A., Huéscar, E., Peco, N., Alarcón, E., \& Cervelló, E. (2012). Desarrollo y validación de escalas para la medida de la comunicación en Educación Física y relación con la motivación intrínseca. Universitas Psychologica, 11(3), 957-967.

Moreno-Murcia, J. A., Martínez-Galindo, C., Moreno, V., Marcos Pardo, P. J., Conte, L., \& Moreno González, R. (2012). Motivación, creencias de habilidad e intención de ser físicamente activo al finalizar la Educación obligatoria. Revista Mexicana de Psicología, 29(2), 175-183.

Moreno-Murcia, J. A., Moreno, R., \& Cervelló, E. (2007). El autoconcepto físico como predictor de la intención de ser físicamente activo. Psicología y Salud, 17(2), 261-267.

Moreno-Murcia, J. A., \& Sánchez-Latorre, F. (2016). The effect of autonomy support in physical education classes. Ricyde, 
12(43), 79-89. https://doi.org/10.5232/ ricyde2016.04305

Ommundsen, Y., \& Roberts, G. (1999). Effect of motivational climate profiles on motivational indices in team sport. Scandinavian Journal of Educational Research, 9(6), 389-397.

Sallis, J. F., \& Hovell, M. F. (1990). Determinants of exercise behavior. Exercise $\mathbb{E}$ Sport Sciences Reviews, 18, 307-330.

Sánchez-Oliva, D., Leo, F. M., Amado, D., Pulido, J. J., \& García-Calvo, T. (2015). Análisis de los perfiles motivacionales y su relación con los comportamientos adaptativos en las clases de educación física. Revista Latinoamericana de Psicología, 47(3), 156-166. https://doi.org/10.1016/ j.rlp.2015.06.007

Shephard, R. J., \& Trudeau, F. (2000). The legacy of physical education: Influences on adult lifestyle. Pediatric Exercise Science, 12(1), 34-50. https://doi.org/10.1123/pes.12.1.34

Sicilia, A., Águila, C., González-Cutre, D., \& Moreno, J. A. (2010). Factores motivacionales y experiencia autotélica en el ejercicio físico: propuesta de un modelo explicativo. Universitas Psychologica, 10(1), 125-135.

Sicilia, A., Moreno, J. A., \& Rojas, A. J. (2008). Motivational profiles and flow in physical education lessons. Perceptual and Motor Skills, 106(2), 473-494. https:// doi.org/10.2466/PMS.106.2.473-494

Tipler, D., Marsh, H. W., Martin, A. J., Richards, G. E., \& Williams, M. R. (2004, July). An investigation into the relationship between physical activity motivation, flow, physical self-concept and activity levels in adolescence. In H. W. Marsh, J. Baumert, G. E. Richards \& U. Trautwein (Eds.), Self-concept, motivation and identity: Where to from here? Proceedings of the Third International Biennial SELF Research Conference. Max Planch Institute, Berlin.

Wall, M., \& Côté, J. (2007). Developmental activities that lead to dropout and investment in sport. Physical Education and Sport Pedagogy, 12(1), 77-87. https:// doi.org/10.1080/17408980601060358

Weidong, L., Bo, S., Rukavina, P. B., \& Haichun, S. (2011). Effect of perceived sport competence on intentions to exercise among adolescents: Mediating or moderating? Journal of Sport Behavior, $34(2), 160-174$.

Zhang, T., Solmon, M. A., Kosma, M., Carson, R. L., \& Gu, X. (2011). Need support, need satisfaction, intrinsic motivation, and physical activity participation among middle school students. Journal of Teaching in Physical Education, 30(1), 51-68. https:// doi.org/10.1123/jtpe.30.1.51

\section{Notes}

* Artículo de investigación. 